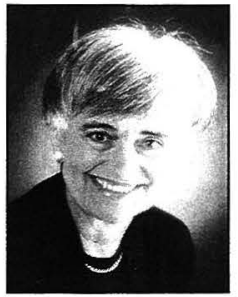

\title{
THE EMPLOYMENT EXPERIENCES OF RECENT KOREAN IMMIGRANTS IN NEW ZEALAND
}

\author{
Jacqueline Lidgard and Hong-key Yoon \\ University of Waikato, \\ University of Auckland
}

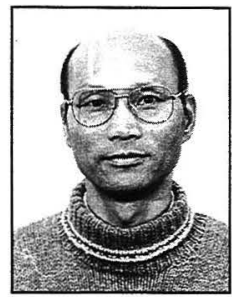

\begin{abstract}
The employment experiences of recent Korean settlers in New Zealand are examined from both a macro and a micro perspective. The macro perspective is based on the analysis of census data. The micro perspective features a small longitudinal study of recent immigrants living in both Auckland and Hamilton - first interviewed between November 1995 and February 1996 and reinterviewed between June and August 1998. The Korean experience in New Zealand in the 1990's seems to differ from that of other earlier overseas Korean immigrants. Levels of self-employment are high amongst recent Korean settlers; many operating small ethnic businesses patronised by Koreans. Analysis suggests that much of this self-employment generates supplementary rather than primary income.
\end{abstract}

Key words: immigration, employment, Koreans, New Zealand

When Air New Zealand announced the cessation of its service to Korea the day after Christmas in 1997 it signalled a dramatic change in the number of people travelling between the two countries. The flood tide of immigrants and tourists from Korea to New Zealand had well and truly begun to ebb.

As has been pointed out elsewhere (Yoon, 1998) New Zealand's relationship with Korea did not really begin until the New Zealand Government sent a military unit to the Korean War. At that time Korea was a war torn country more of a liability than a potential market and an unimportant nation to Westerners. Winston Churchill may well have summed up the general feeling of New Zealanders when in July 1953 he declared:

"If I were in charge I would withdraw the United $\mathrm{Na}$ tions troops to the Coast ... Korea does not really matter now. I'd never heard of the bloody place until I was seventy-four"

(re-quoted from Halliday and Cumings, 1988)

This impression of Korea persisted throughout the $1960 \mathrm{~s}$ and 1970's when the trade relationship between the two countries was insignificant. In 1970 New Zealand's exports to Korea were valued at NZ\$1.6 million while imports from Korea were only worth NZ\$0.5 million (New Zealand Embassy, Seoul, 8). With the rebuilding of Korea in the 1980 's and the continuing decline of trade with Britain Korea became a potentially large market. The value of exports to Korea jumped from the 1970 level of NZ\$1.6 million to NZ\$64 million in 1980, to NZ\$501.8 million in 1990 and was NZ\$1,028.0 million in 1996 (New Zealand Embassy, Seoul, 8; New Zealand Yearbook, 1998, 523). Currently Korea is New Zealand's fifth largest export market (New Zealand Yearbook, 1998, 526).

The growth rate of the population of the Korean residents born in Korea in New Zealand has been as dramatic as the growth rate of the trade relationship. Twenty-two years ago, the Korean community in Auckland numbered little more than 20 residents (Yoon, 1998). The Korean population in Auckland at the 1996 census was 8,847 (69 percent of the total Korean population) and 7,620 of these people had arrived in New Zealand between 1991 and 1996. Clearly recent Korean immigration to New Zealand has undergone exponential growth.

This paper begins with a general comment on the relevant political and policy changes that have brought about this dramatic growth. It then details the changes in the pattern of permanent and long-term arrivals and departures of the Koreans between 1995 and 1998. The second section is a macro profile of the Korean population using data collected in the 1996 Census of Population and Dwellings. The micro perspective is confined to the experiences of a group of Koreans who were first interviewed at the end of 1995 and the beginning of 1996 and were reinterviewed in 1998. The final paragraph indicates some of the future research implications of this paper.

\section{Relevant political and policy changes}

The immigration policy changes in New Zealand that brought about the arrival of large numbers of immigrants 
from Northeast Asia followed a change in 1984 to a government containing activists intent on changing the country's strong interventionist economy into a "free market" one. Fortuitously countries experiencing rapid economic expansion shared the region to which New Zealand belonged geographically. The successive changes in immigration policy since 1986 (Burke, 1986; New Zealand Immigration Service, 1991; 1995; 1998) have highlighted the deficiencies in the policy and the inadequacies of relevant research. The New Zealand government, through a succession of Ministers, has not been able to establish a consistent medium term immigration policy despite intentions in this direction expressed in 1991 when the point system was introduced and in 1997 at the Population Conference (Bradford, 1997a).

The reality of the 1995 policy adjustments was that the number of immigrant applications immediately began to decline although this was not shown in arrival figures until around March/April 1996 (New Zealand Immigration Service, 1997) (Figure 1). The decline in approvals was particularly marked for people from Taiwan and the Republic of Korea and was attributed directly to 'new English language requirements, new requirements for returning residents' visas ... and occupational registration requirements' (New Zealand Immigration Service, 1997, 4).

In August 1998, just after the round of interviews reported in this paper was completed, a cabinet reshuffle saw the appointment of a new Minister of Immigration (Tuariki Delamere, a Minister outside of cabinet again). One of his first statements about his new portfolio was to concede that an immigration policy blunder had left "hundreds of highly skilled settlers facing the prospect of never working in their chosen profession in New Zealand" (Stone, 1998, A1). Mr Delamere said that the presence in New Zealand of hundreds of out of work professionals had arisen, as there had been a misunderstanding between the professional bodies and the Immigration Department. Previous government policy had not been deliberately set to mislead people, according to Mr Delamere, but the fact remains that hundreds of highly qualified immigrants are under- or unemployed. Clearly the New Zealand government "deserves to be embarrassed by the plight of too many professional migrants" (Stone, 1998, A1).

On 12th October 1998, the New Zealand Government announced a new immigration package in an effort to make "New Zealand a more attractive destination" (Delamere, $1998,1)$. This included "the abolition of the English language bond, . . . a more realistic view of what qualifications should be accepted under the General Skills category ... and [acceptance of] all work experience not just experience relevant to qualifications" (Delamere, 1998, 1). This latter change will help to address the concern about the lack of recognition of prior work experience reported after the first interviews in 1996 (Lidgard, 1996, 37). In general the changes are an attempt by government to ensure that New Zealand is perceived as a welcoming destination for those with skills and investment capital. It is rather ironic that the government should again take a more proactive approach to immigration at a time when the New Zealand economy has begun to suffer from a contraction in its exports to Asian markets.

\section{Permanent and long-term migration}

There is always a lag between approvals for entry to New Zealand and the actual arrival of immigrants in the country. The immigration policy changes in 1995 did not begin to show up in the net migration figures until the year ended 31 March 1997. In this year the net PLT gain from countries in the Asian region was 21,528, 3,684 less than the net gain during the previous 12 months $(25,212)$. The reduced

Table 1. Permanent and long-term net migration by nationality, 1995-1998

a) Regions in Asia

\begin{tabular}{ccccc}
\hline $\begin{array}{c}\text { Year ended } \\
\text { 31 March }\end{array}$ & $\begin{array}{c}\text { Northeast } \\
\text { Asia }\end{array}$ & $\begin{array}{c}\text { Southeast } \\
\text { Asia }\end{array}$ & $\begin{array}{c}\text { South } \\
\text { Asia }\end{array}$ & $\begin{array}{c}\text { Asia } \\
\text { Total }\end{array}$ \\
\hline 1995 & 12,243 & 3,255 & 2,551 & 18,049 \\
1996 & 16,665 & 3,648 & 4,899 & 25,212 \\
1997 & 14,179 & 2,902 & 4,447 & 21,528 \\
1998 & 8,609 & 1,553 & 2,406 & 12,568 \\
\hline
\end{tabular}

b) Countries in Northeast Asia

\begin{tabular}{rrrrr}
\hline $\begin{array}{l}\text { Year ended } \\
\text { 31 March }\end{array}$ & Korea & Taiwan & Hong Kong & $\begin{array}{r}\text { China } \\
\text { (PRC) }\end{array}$ \\
\hline 1995 & 3,405 & 2,246 & 2,385 & 2,158 \\
1996 & 3,845 & 3,861 & 2,331 & 4,272 \\
1997 & 2,312 & 2,948 & 2,090 & 4,053 \\
1998 & 117 & 1,853 & 1,054 & 3,041 \\
\hline
\end{tabular}

Source: Unpublished data files prepared by the Customer Services Division of Statistics New Zealand 
Figure 1. Permanent and long-term arrivals and departures of Korean nationals, 1 April 1990 - 31 March 1998

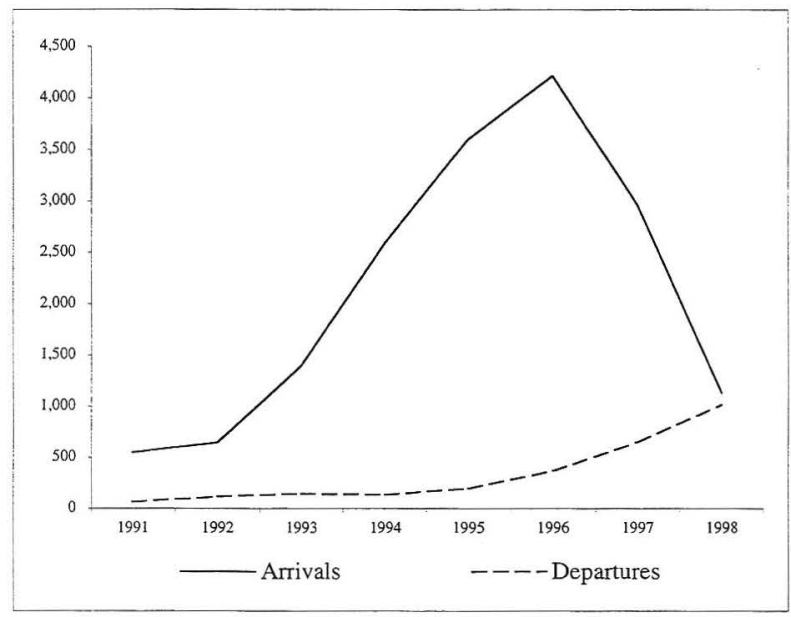

number of approvals for entry after the policy changes, combined with the onset of the Asian economic crisis and these flowed through to a significant fall in the net PLT migration figures for this region in the year ending $31 \mathrm{March}$ 1998. The net gain for this year was $12,568-8,960$ less than in the previous 12 month period.

The biggest decline was in the net gain from countries of Northeast Asia, especially from the Republic of Korea (hereafter referred to as Korea). In the year ended $31 \mathrm{March}$ 1997 the net PLT gain to New Zealand from countries of Northeast Asia was 14,179 (2,312 from Korea); during the subsequent 12 months the gain was reduced to 8,609 (117 from Korea) as shown in Table 1 (b).. This represented a decline of 39 percent in 12 months over the sub-region as a whole and 95 percent in the case of Korea.

Some of the more important reasons behind the dramatic decline of Korean net PLT migration since 1997 include the 1995 immigration policy change which introduced the English language test. English is a difficult language for Koreans, much more difficult than for the Chinese, and hence the introduction of this test frightened away many prospective Korean applicants. In addition immigration consultants stopped recommending New Zealand as a possible destination after the English language test was required. They realised that the majority of Korean applicants would not pass the test and they would not be able to charge a full fee for handling their immigration. Therefore they recommended other countries which do not require an English language test, such as Canada, as a possible destination.

The dramatic decline in the PLT net migration of Koreans is also a reflection of the nature of chain migration. Koreans came to New Zealand through various connections including high school and university alumni connections, regional connections and other friends and relatives (blood line connections). When they heard about the changed immigration situation and difficulty of settling in New Zealand, they did not apply for entry permits.

The economic crisis and the change in the exchange rate have also impacted on the net migration figures. The sudden collapse of the Korean economy caused much hardship for most Koreans. First, it sharply reduced their assets (for instance, there was a sharp decline of property values). This made it difficult for them to raise enough funds to migrate to New Zealand. Second the change in the currency exchange rates with the collapse of Korean Won and high Korean bank interest rates encouraged overseas Koreans to send their money back to Korea to take advantage of the situation. There was little incentive for Koreans in Korea to change their money into foreign currencies at such a poor exchange rate.

It is difficult to isolate the effects of the immigration policy changes from the links to the complex economic changes 
Table 2. Population change 1986-1996, Asian ethnic groups

\begin{tabular}{|c|c|c|c|c|c|}
\hline \multirow[b]{2}{*}{ Ethnic Group 1} & \multicolumn{3}{|c|}{ Census } & \multicolumn{2}{|c|}{$\begin{array}{c}\text { Change between } \\
1986-1996\end{array}$} \\
\hline & 1986 & 1991 & 1996 & Number & Percent \\
\hline Chinese & 26,616 & 44,793 & 81,309 & 54,693 & 206 \\
\hline Korean & 441 & 927 & 12,753 & 12,312 & 2,792 \\
\hline Total Asian & 53,541 & 99,576 & 173,502 & 119,961 & 224 \\
\hline Total NZ & $3,263,283$ & $3,373,926$ & $3,618,303$ & 355,020 & 11 \\
\hline
\end{tabular}

1 Where a person reported more than one ethnic group, they have been counted in each applicable group.

Source: Ho, Goodwin, Bedford and Spragg, 1997, 1

in the Asian region in these changing patterns of PLT migration. Clearly the downward trend in the net gains and the number of PLT arrivals from this region, and in particular from Korea, have been intensified by both the 1995 immigration policy changes and the Asian financial crisis. The next section shows the effects of these changes on the arrivals and departures of Koreans during the 1990s.

Changes in permanent and long-term arrivals and departures, 1991-1998

The arrivals and departures of Korean PLT nationals between 1 April 1991 and 31 March 1998 are shown in Figure 1. It needs to be kept in mind that these statistics should be used as an indicator of a trend rather than as an accurate reflection of PLT arrivals and departures. The reasons for this are twofold. First, some short-term arrivals (such as visitors or students) change their visa status to PLT after they arrive in the country. Second, a considerable number of Korean PLT departures are in fact not recorded as such. Koreans who have declared New Zealand citizenship are no longer classified as Koreans when they leave New Zealand. Also when Koreans return to Korea on a more or less PLT basis (for employment in Korea), they may not declare their departure as PLT, because they intend to make frequent return visits to their family in New Zealand (normally wife and children). In addition they may intend to return to live in New Zealand on a permanent basis after working in Korea for two or three years. For these reasons we need to take care when analysing PLT statistics for new immigrants.

With this in mind it can be seen that the pattern of arrivals of Koreans did not reach four figures until the year ended 31 March 1993. The sudden drop in the number of PLT arrivals of Korean nationals in the year ending 31 March 1997 was a reflection of the effect of the English language requirement policy change in October 1995 and has already been commented on. At the same time as the level of arrivals of Koreans on a PLT basis was dropping significantly the number of departures on a permanent or long-term basis was rising (Figure 1). The number of Koreans departing in the year ending 31 March 1995, after a stay of 12 months or more in New Zealand was under 200.

By the 31 March 1996, the numbers of Koreans leaving New Zealand were beginning to rise and they continued to rise sharply for the following two years until over 1,000 Koreans left on a PLT basis in the year ending 31 March 1998 (Figure 1). Factors associated with the October 1995

Table 3. Overseas-born Korean population living in Auckland and elsewhere in New Zealand in 1996 by usual residence in 1991

\begin{tabular}{|c|c|c|c|c|c|c|}
\hline & \multicolumn{5}{|c|}{ Usual Residence in 1996} & \\
\hline & \multicolumn{2}{|c|}{ Auckland } & \multicolumn{2}{|c|}{ Elsewhere NZ } & \multicolumn{2}{|c|}{ Total NZ } \\
\hline & No & $\%$ & No & $\%$ & No & $\%$ \\
\hline \multicolumn{7}{|l|}{ Overseas-born } \\
\hline NZ Resident 1991 & 390 & 3 & 291 & 2 & 681 & 5 \\
\hline Overseas 1991 & 7,620 & 60 & 3,225 & 25 & 10,845 & 85 \\
\hline Not defined & 414 & 3 & 183 & 1 & 597 & 5 \\
\hline Total overseas-born & 8,424 & 66 & 3,699 & 29 & 12,123 & 95 \\
\hline Born in NZ & 297 & 2 & 159 & 1 & 456 & 4 \\
\hline Unspecified birthplace & 126 & 1 & 48 & 0 & 174 & 1 \\
\hline Total Korean Poulation & 8,847 & 69 & 3,906 & 31 & 12,753 & 100 \\
\hline
\end{tabular}

Source: Ho, Goodwin, Bedford and Spragg, 1997, 3 
immigration policy changes and the Asian economic crisis have combined to impact severely on the PLT flows between New Zealand and countries of Northeast Asia, particularly Korea. The following section profiles the Korean population. The survey participants whose experience is detailed later in the paper are a part of this recent Korean immigrant group.

\section{Macro-perspective of Korean population}

\section{Growth and distribution}

New Zealand's Asian population more than tripled between 1986 and 1996 (Table 2). While the New Zealand population as a whole recorded almost an 11 percent change in the decade the change in the same time period for the total Asian population was 224 percent skilled workers, the following table focuses on the 20-49 year age group. The total number of "recent" immigrants, which includes the New Zealand born returnees, aged 2049 years in the 1991 and 1996 censuses is shown in Table 4. This table also shows the number of recent Korean immigrants who were born in Korea. Also included for comparison is the total of all the overseas born and the New Zealand born who were living overseas five years ago.

The New Zealand born and overseas born populations grew by relatively similar proportions ( 28 and 31 percent respectively) between 1991 and 1996 . This gives the rather misleading impression that immigrant and non-migrant groups grew at roughly the same rate during the intercensal period. Table 4 shows that the Korean population grew 52 times more than the average for the entire overseas-born.

\section{Table 4. Number of New Zealand born, total overseas born, Korea-born and total "recent" immigrants, 1991 and 1996 censuses, in New Zealand, aged 20-49 years}

\begin{tabular}{llll|lllc}
\hline $\begin{array}{l}\text { Birthplace/ } \\
\text { Ethnicity }\end{array}$ & Male & Female & Total & Male & Female & Total & $1991-96$ \\
\hline New Zealand & 19,068 & 20,472 & 39,540 & 24,738 & 25,698 & 50,436 & $28 \%$ \\
Overseas & 34,273 & 34,710 & 68,983 & 42,669 & 47,796 & 90,465 & $31 \%$ \\
Total & $\mathbf{5 3 , 3 4 1}$ & $\mathbf{5 5 , 1 8 2}$ & $\mathbf{1 0 8 , 5 2 3}$ & $\mathbf{6 7 , 4 0 7}$ & $\mathbf{7 3 , 4 9 4}$ & $\mathbf{1 4 0 , 9 0 1}$ & $30 \%$ \\
\hline Korea & 168 & 180 & 348 & 2,850 & 3,135 & 5,985 & $1,620 \%$ \\
\hline
\end{tabular}

Source: Unpublished data files prepared by the Customer Services Division of Statistics New Zealand from the 1991 and 1996 Censuses of Population and Dwellings

The census in 1996 showed that the fastest growing Asian ethnic group during this decade was the Korean one. As shown in Table 2 by 1996 the Korean community was almost 28 times as large as it had been ten years previously in 1986. Therefore it is not surprising to find that 95 percent of the Korean population at the 1996 census was born overseas and 85 percent were living overseas in 1991 (Table 3).

In addition, the impact of immigration on New Zealand's population is not spread evenly across the country. As in other parts of the world it is highly concentrated in particular cities. Auckland has been the favoured initial destination for overseas born immigrants for much of the twentieth century. This preference has been particularly strong for Asian immigrants over the past decade (Bedford and Goodwin, 1997; Bedford, Goodwin, Ho and Lidgard, 1997). The majority of Koreans live in the Auckland metropolitan area - 69 percent (Table 3 ). Out of a total Korean population of 8,847 in Auckland 7,620 are recent arrivals.

\section{Labour force age group}

As the 1991 immigration policy changes introduced a points system of selection in a more determined attempt to attract

\section{Qualifications and employment}

The total number of Koreans living in Auckland and elsewhere in New Zealand who were 20 years old and over and who had been living overseas when the census was conducted in 1991 (the "recent" immigrants) are shown in Table 5. As the New Zealand immigration policy since 1991 has specifically targeted those with high academic qualifications, it was not surprising to find that those who had arrived in New Zealand since the 1991 census recorded a high incidence of tertiary qualifications. Just over 50 percent of the males and just over 40 percent of the female Koreans born in Korea had tertiary qualifications.

Korean men living in Auckland had the highest percentage in the labour force ( 57 percent) with an average of just over 50 percent across the country as a whole. When the labour force participation rate is studied by age group, it is the 30 39 year old males living in Auckland that have the highest labour force participation rate. The Korean males have the highest rate ( 67 percent). The participation rates tend to be lower for the same groups living outside the Auckland area with the Koreans being 20 percentage points lower in other parts of New Zealand (Table 5). Data from the 1996 Census shows that unemployment is a significant problem for 
Table 5. Total number of Korean "recent" immigrants, by birthplace, aged 20 years and over, living in Auckland and elsewhere in New Zealand in the 1996 Census, percentages of total, tertiary qualifications and labour force

\begin{tabular}{|c|c|c|c|c|c|c|}
\hline \multirow[b]{3}{*}{ Migrant group } & \multicolumn{6}{|c|}{ Usual Residence in 1996} \\
\hline & \multicolumn{2}{|c|}{ Auckland } & \multicolumn{2}{|c|}{ Elsewhere NZ } & \multicolumn{2}{|c|}{ Total NZ } \\
\hline & M & $\mathrm{F}$ & M & $\mathrm{F}$ & M & $\mathrm{F}$ \\
\hline Total no. $20+$ years & 2,190 & 2,385 & 942 & 972 & 3,132 & 3,357 \\
\hline Percentage of total in NZ & 70 & 71 & 30 & 29 & 100 & 100 \\
\hline Percent with tertiary quals & 54 & 41 & 54 & 46 & 54 & 42 \\
\hline Percent in labour force & 57 & 34 & 42 & 28 & 52 & 32 \\
\hline
\end{tabular}

Source: Unpublished data files prepared by the Customer Services Division of Statistics New Zealand from the 1996 Census of Population and Dwelling.

those in the labour force, for both of these migrant groups (Table 6).

\section{Employment status}

The highest proportion of wage and salary earners was found amongst the Korean males in Auckland although the percentage was less than 30 (Table 6). One in four of the recent immigrant Korean men in the labour force living elsewhere in New Zealand categorised themselves as wage and salary earners. The women had a slightly lower percentage earning a wage or salary ( 23 percent).

One in five Koreans (males 21 percent and females 23 percent) were unemployed. There appears little difference in the rate of unemployment between those migrants living in Auckland and those living elsewhere in New Zealand.

Higher proportions of the Korean recent immigrants were in self-employment rather than in waged employment. The Koreans of both sexes living in Auckland had the highest level of self-employment - 38 percent of the males and 29 percent of the females.

Rates of self-employment were higher in the Auckland area than elsewhere in New Zealand and rates increased with age. For example the Korean men in their fifties living in
Auckland had a twenty percent higher rate of self-employment than the Korean men in their thirties (Table 7). This pattern follows the expectation that it will be the older immigrants, who have had time to accumulate significant capital, who will be in the best position to begin new business enterprises. The age group with the highest levels of selfemployment was the 40 to 59 year old Koreans from Korea with more than half working in this category.

In recent years, the debate about the economic effects of migrant entrepreneurial activities on the host community has become more sophisticated. Recent empirical research from Australia and Canada found that immigrant entrepreneurship could not in itself raise productive efficiency across the broader economy (Foster, Gruen and Swan, 1994). These authors also suggested that there are "other considerations - such as social, demographic, humanitarian and environmental issues - [which] should form the main arena in which the immigration debate and policy formulation are conducted" (Foster, Gruen and Swan, 1994, 471).

On another level, research also found that simple cultural explanations of entrepreneurial abilities, such as motivation and flexibility, are no longer adequate in explaining the success or failure of particular migrant groups $(\mathrm{Li}$, 1993). The environment into which the entrepreneurs move,

Table 6. Employment status among the Korean "recent" immigrants, by birthplace, in the labour force, aged 20 years and over, living in Auckland and elsewhere in New Zealand in the 1996 Census

\begin{tabular}{|c|c|c|c|c|c|c|}
\hline \multirow[b]{3}{*}{ Employment status } & \multicolumn{6}{|c|}{$\begin{array}{l}\text { Usual Residence in } 1996 \\
\text { (percentage of over } 20 \text { year olds) }\end{array}$} \\
\hline & \multicolumn{2}{|c|}{ Auckland } & \multicolumn{2}{|c|}{ Elsewhere NZ } & \multicolumn{2}{|c|}{ Total NZ } \\
\hline & $\mathbf{M}$ & F & $\mathrm{M}$ & $F$ & $\mathrm{M}$ & F \\
\hline Wage and salary & 28 & 23 & 25 & 24 & 27 & 23 \\
\hline Self-employment & 38 & 29 & 25 & 19 & 35 & 26 \\
\hline Unemployed & 21 & 23 & 23 & 22 & 21 & 23 \\
\hline Not specified & 13 & 27 & 25 & 35 & 17 & 28 \\
\hline
\end{tabular}

Source: Unpublished data files prepared by the Customer Services Division of Statistics New Zealand from the 1996 Census of Population and Dwelling. 
and the institutions through which they develop their business connections and activities are also of critical importance to migrant success. Whether a migrant is able to build a successful business depends as much on these factors as on the particular cultural attributes he or she possesses (Chan and Chiang, 1994). These issues are discussed in greater detail in the proceedings of a workshop on Chinese entrepreneurial activities in New Zealand (Ho, Bedford, Wong and Tang, 1998; Skeldon, 1998).

\section{Sources of income}

To conclude the profile of the recent Korean immigrants born in Korea the sources of income are examined (Table 8). Although there were relatively high levels of self-employment in this migrant group it appears that many of these businesses do not generate a significant amount of income for the immigrant entrepreneurs. When Tables 8 and 9 are compared, it is clear that there are more people who state they are receiving income from interest on investments rather than from self-employment.
The Korean males living in Auckland have the highest percentage ( 23 percent) receiving income from self-employment. A comparison of this group's employment status and source of income, however, shows a percentage difference of 15 points between those self-employed 38 percent ( $\mathrm{Ta}$ ble 7) and those whose income is from self-employment 23 percent (Table 8).

The census question from which Table 7 is derived asked for 'ALL the ways you yourself get income' (Statistics New Zealand, 1996). It has not been possible to differentiate between the major and "other" sources of income in this table. However, when the percentage listing self-employment as their major form of labour force-participation is higher than those listing self-employment as a source of income it is assumed that many of those in self-employment are not receiving much income from this source.

This brief examination of the 1996 census shows that it is difficult to generalise about the experiences of recent immigrants. Their labour force participation varies by age,

Table 7. Self-employment among Korean "recent" immigrants, by birthplace, in the labour force, aged 20 years and over, living in Auckland and elsewhere in New Zealand in the 1996 Census

\begin{tabular}{lcccccc}
\hline & \multicolumn{5}{c}{ Usual Residence in 1996 } \\
Age group & \multicolumn{2}{c}{ Auckland } & \multicolumn{2}{c}{ (percentage of over 20 year olds) } & \multicolumn{2}{c}{ Total NZ } \\
\hline 20-29 years & M & F & M & F & M & F \\
30-39 years & - & - & 0 & - & - & - \\
40-49 years & 34 & 28 & 25 & - & 34 & 27 \\
$50-59$ years & 51 & 41 & 33 & - & 47 & 40 \\
60+ years & 55 & - & - & - & 51 & - \\
Total 20+ years & - & - & - & 0 & - & - \\
\hline
\end{tabular}

Note: - Proportions not given when numbers are less than 25

Source: Unpublished data files prepared by the Customer Services Division of Statistics New Zealand from the 1996 Census of Population and Dwelling.

Table 8. Sources of income in New Zealand among the Korean "recent" immigrants, by birthplace, aged 20 years and over, living in Auckland and elsewhere in New Zealand in the 1996 Census

\begin{tabular}{|c|c|c|c|c|c|c|}
\hline \multirow[b]{3}{*}{ Sources of income } & \multicolumn{6}{|c|}{$\begin{array}{l}\text { Usual Residence in } 1996 \\
\text { (percentage of over } 20 \text { year olds) }\end{array}$} \\
\hline & \multicolumn{2}{|c|}{ Auckland } & \multicolumn{2}{|c|}{ Elsewhere NZ } & \multicolumn{2}{|c|}{ Total NZ } \\
\hline & $\mathrm{M}$ & $\mathrm{F}$ & $\mathrm{M}$ & $\mathrm{F}$ & $M$ & $\mathrm{~F}$ \\
\hline Wages & 22 & 16 & 18 & 14 & 21 & 16 \\
\hline Self-employment & 23 & 18 & 14 & 11 & 20 & 16 \\
\hline Interest & 30 & 36 & 30 & 33 & 30 & 35 \\
\hline Unemployment benefit & 4 & 4 & 4 & 5 & 4 & 4 \\
\hline Student benefit & 11 & 7 & 22 & 20 & 14 & 11 \\
\hline Other Government benefit & 6 & 10 & 5 & 9 & 6 & 9 \\
\hline Other sources & 4 & 9 & 7 & 8 & 6 & 9 \\
\hline
\end{tabular}

Source: Unpublished data files prepared by the Customer Services Division of Statistics New Zealand from the 1996 Census of Population and Dwelling. 
gender and the New Zealand locality in which they have chosen to settle. From the figures on unemployment, wage and salary earners and self-employment, it appears there are a considerable number of skilled migrants from Korea who are both unemployed and underemployed. This suggests that many of these new immigrants have experienced greater than expected difficulty in settling in New Zealand.

Some of the experiences of the migrants who came to New Zealand before the 1995 policy changes and were reinterviewed in 1998 are now presented. This material will help to establish some of the reasons why recent immigrants from Korea are unemployed, working in low-status jobs or participating in some form of self-employment.

\section{Micro-perspective - experiences of participants}

Even at the best of times, migration is a disruptive experience. Just how disruptive this process is and how the immigrants handle life in their "new" country is not something that can be analysed using census statistics. The interview process is important in gathering the data to present the perspective of the immigrants and to gain some insights into the social adaptation process. Between November 1995 and February 1996 a group of 14 "recent" immigrants from Korea were interviewed. These interviews were part of a larger project in which forty-two "recent" immigrants from Korea, Taiwan and Hong Kong in Auckland and Hamilton were interviewed as part of a larger study of migration between Northeast Asia and New Zealand (Lidgard, 1996). As 37 of the original group of 42 ( 88 percent) had arrived in New Zealand after the 1991 Census they were all part of the 1996 census "recent" immigrant group whose selected characteristics have been analysed in the previous section. As many as possible of the group of immigrants interviewed between November 1995 and February 1996 (Lidgard, 1996) were reinterviewed between February and August 1998. The main objective of the follow-up survey was to study the changes over time in the adaptive experiences of these immigrants in order to determine the impact of duration of residence in New Zealand on their occupational and social integration.

\section{Methodology}

Ten of the original 14 participants from Korea were reinterviewed in 1998. Of the four that were not, two had returned to Korea, one family had relocated from Hamilton to Wellington in search of further qualifications and better job prospects and one family was not able to be traced. Two additional interviews were conducted - one in Auckland and one in Hamilton - with Koreans who had been in New Zealand for at least two and a half years to provide additional information about the Korean community.

In addition to questions relating to employment issues the participants were asked whether they had undertaken any further education or training courses and the reasons for taking them and whether their work status and income sources had changed. Also surveyed was the participant level of satisfaction with their situation. This enabled them to detail some of their experiences as they adjusted to changes in life since their arrival in New Zealand.

\section{Some characteristics}

\section{Family type}

The current family living arrangements were compared with the living arrangements of the participants at the time of the first interviews. In 1995/9690 percent of the group were living in New Zealand as a nuclear family. In 1998 one family that had originally settled in New Zealand as a nuclear family unit were now in the country as an "astronaut" family. It should be noted here that "astronaut" is the term used to describe the family arrangement where the husband settles his family in a new country and continues to pursue his business or profession in his home country and commutes between the two countries. Specifically it is the term used among the Hong Kong Chinese and to some extent, the Taiwanese. The Koreans talk of the "grass widow" or the "saengkwapu" family.

\section{Table 9. Main characteristics of Korean Participants}

\begin{tabular}{lc}
\hline & Number \\
\hline Gender & \\
Male & 7 \\
Female & 3 \\
\hline
\end{tabular}

\section{Age}

$\begin{array}{ll}30-39 \text { years } & 6 \\ 40-49 \text { years } & 3 \\ 50-59 \text { years } & 1\end{array}$

Highest education level
Diploma and above
Secondary school

Family living arrangement

Whole family in New Zealand $\quad 8$

Husband living overseas

2

\section{Reasons for migration}

Children's education 6

Lifestyle

6

3

Environment

2

Business

The family that had adopted the "grass widow" structure since the first interview had done so to enable the husband to return to work that he was experienced in and enjoyed. In New Zealand he had struggled for almost three years to establish a viable business. In 1998 eight of the ten families were nuclear families and two were "grass widow" families (Table 9). 


\section{Education and qualifications}

Since the first study in 1995/96 some participants had completed courses of study. Three participants had completed short (six month) English language courses at a polytechnic. One of these participants was currently studying his third Polytechnic course. By continuing to study introductory courses he felt he was improving both his English language skills and his knowledge of "kiwi culture". The course content was chosen for interest rather than as a retraining course that might lead to employment.

A vocational qualification directly related to his self-employment had been completed by one of the self-employed participants. Another participant had a spouse who was just completing a retraining course undertaken in the hope that it might lead to employment. The participant, who when first interviewed was studying a three year course for a professional qualification, withdrew from the course after a year on medical advice. This case will be commented on in detail later. In addition one participant was attending a bible school and another attended an occasional recreational night-class to learn new skills and gain a better understanding of the local culture.

\section{Economic incorporation}

In the earlier interviews, it had been found that "chances of gaining employment improve with duration of residence in New Zealand" (Lidgard, 1996, 32). There was also evidence of this happening in the Winkelmann study (Winkelmann, 1997). Whether the employment and financial situation of the participants had improved in the two and a half years since they were first interviewed is explored below.

\section{Work situation of participants}

Some found the experiences of looking for a job extremely frustrating. As a detailed case study below will show one participant, who had been a student retraining in 1995, had made about 100 job applications and when reinterviewed had not been successful in getting a job. Overall, many participants still felt generally apprehensive about New Zealand business practices and culture, and were still critical of the level of post-migration assistance from the government to facilitate their investment efforts. The current work situation of Koreans in New Zealand, as reflected by those who were interviewed, fall into the following categories; paid employee, self-employed, student, retired, not working, seeking work, and working overseas.

\section{Paid employee}

Only one of the participants was a full-time paid employee and he was continuing to work in the job he was working in at the first interview. He said it had been easy to get a job as he was prepared to do any kind of work. He was underemployed however, as he was a qualified engineer working as a cleaner and handy man in New Zealand. In addition to his full-time waged employment he worked on a part-time basis, helping his wife to run an ethnic restaurant. At the time of the second interview the couple had sold their original business and started a new one at the beginning of 1998. They mentioned that seeing me again made them realise how much they had grown in the past two and a half years.

\section{Self-employed}

Four of the ten participants were self-employed. Three were continuing to run the same businesses they had been running in 1996, one had bought the business he had been planning to buy at the first interview and another had returned to work overseas. The businesses ranged from a deer velvet export business, a horticultural export business, and an entertainment business to an Asian food market.

All of the businesses reported that they were struggling in 1998. The downturn in Korean exports was a major factor affecting the export businesses while the billiard hall, bought in 1996 as an established business, reported competition from a new business that had opened across the road. The Asian food market had also been bought as an established business but turnover had decreased and costs were rising and the woman participant was finding it hard work running the business and caring for her two young children.

The participant who was operating the deer velvet export business in New Zealand is an example of an experienced businessman who has established a business in New Zealand that he was familiar with before emigration. He originally came to New Zealand in 1990 at the request of a family friend to establish this business in Christchurch. After almost five years he moved the business to Auckland as "Auckland is the centre of commerce in New Zealand and is therefore a better place to do business than Christchurch" (Lidgard, 1996, 25). When first interviewed he was critical of government policies in New Zealand and the difficulties they created for companies like his to set up in business and find suitable employees (Lidgard, 1996, 31).

At the reinterview in 1998 New Zealand government policies were again criticised. This businessman feels that the New Zealand government needs to exercise far greater control over the operation of the deer velvet industry. At the moment the lack of quality control or regulations over the export of the product means that inferior quality velvet can be exported. This lack of regulation in the industry allows the exportation of about 10 percent second grade velvet. He was adamant that practices such as these would ruin the reputation of the other 90 percent of the exported product. The danger for business is that these habits spoil the image of the New Zealand product and is bad for both the New Zealand business and the New Zealand deer farmers.

If quality control is not established soon this businessman says the industry will suffer even more, particularly in the current economic climate. Although business has been difficult since the onset of the Korean economic crisis in November 1997 "plunged the country's entire economy into a deep bog" (Seok, 1998, 1), the participant is confident that his long experience in the deer velvet business will enable him to continue to operate his business in New Zealand. 


\section{Student}

Two of the participant group were in the student category in 1998. One woman, listed in the home duty category at the time of the first interview, had become a student and was working toward certification at the completion of her course. Another student, as mentioned earlier, had been continuing to study since 1996 . He felt that by taking courses he was getting a better grounding in the English language with the added benefit of learning new skills. He had helped his wife establish a small service industry and was very involved in their children's education.

\section{Retired}

One of the participants in his mid 40's, who had come to New Zealand under the business investment category in 1994, was still living as a retired worker. He mentioned that he was still considering the possibility of doing business in New Zealand but was finding it very difficult to get started.

\section{Not working, seeking work}

One participant is currently unemployed and actively seeking work. His story shows clearly that even those who arrive with realistic expectations and a well-researched plan for settlement may find that the reality of gaining satisfactory employment, or starting a business, is far more difficult than they expected.

Currently this man is looking for any type of work, either full or part-time in any occupation. When interviewed he had made about 100 job applications ranging from driving, operating a laundry and being a courier to data entry and trainee PC Support Analyst jobs. The avenues he had explored to find work included the Employment Services, newspaper advertisements - both local and national, friends, neighbours and the "Trade and Exchange". These strenuous efforts had been rewarded with two job interviews. The problem as he sees it, is that although he can speak English well it is "not fluently as a native speaker". This problem has been compounded for him at the present time by the economic depression in New Zealand that has created a large pool of locally born unemployed. "These [locally born] are preferred by employers."

To seek help in the problems encountered trying to find work he has consulted both the New Zealand Employment Service and the Citizens Advice Bureau. However, he has become very sceptical about employment services as from his experience "the jobs in the list of the Employment Service are not reliable". When job consultants tried to contact employers for him there were often problems - such as the job had been already filled or withdrawn.

Prior to his emigration to New Zealand he had been managing a construction company in Korea. From conversations with a sister, who had been settled in North America for 30 years, he knew that he would need to allow at least five years to retrain for a job in New Zealand. He decided to become an accountant and enrolled in a three year Bachelor of Business Studies course at a polytechnic.
Unfortunately he was only able to complete 18 months of his course work. At the end of 1996 he was advised to give up his study for health reasons. So in spite of careful research and forward planning he has been unable to obtain a New Zealand professional qualification. In 1997 a keen family interest and involvement in golf sparked the idea for a "homestay" business for Korean students offering a range of organised activities - in particular golf. He was in the process of setting up this business when: "The economic crisis blew everything up". At the beginning of 1998 he began trying to get a job and, as already mentioned, has found the process of submitting numerous job applications very stressful. In the meantime he claims the unemployment benefit and his wife has some part-time, casual work.

\section{Working overseas}

One of the original participants is now working in Korea while his family remains in New Zealand. This businessman, self-employed in New Zealand at the time of the first interview, returned to a job in Korea a few months after the first interview with him was conducted. His wife, who was present at the first interview, was reinterviewed in 1998.

Although this man had succeeded in establishing a business in New Zealand when he was first interviewed in early 1996 , he stressed at the time that it was difficult to set up a profitable business in this country (Lidgard, 1996, 30). When the opportunity for him to work again in Korea became an option the family, who had been living in New Zealand for almost three years, gratefully accepted it. His wife said: "The Korean situation is very hard as it is difficult in New Zealand to work. So when my husband received a call to go back and work in Korea he was very pleased to receive this offer of work." The couple decided it would be best for the family if the husband accepted the job offer and worked in Korea for two to three years. He left New Zealand in June 1996 and his wife was expecting that he would be returning to live full-time in New Zealand before the end of March 1999, or "it could be earlier depending on the [economic] situation in Korea. Now salaries are being cut down and sometimes there are no bonuses. People are working harder for less money".

\section{Sources of income}

Overall it appears that of those who defined themselves as self-employed many were often in a business that merely supplemented their income where the income earned from the business was secondary to that earned from interest on deposits. Some of the participants mentioned that they had heard that many immigrants had moved back to Korea or onto Australia as "business activity is so low in New Zealand they can't afford to stay. Business looks more promising in bigger countries." This is an issue that would benefit from further research.

The main change in the sources of income in the past two years for the participants was that less were reliant on interest and more on overseas remittances than in 1995/96. The percentage receiving income from self-employment 
had remained the same although the participants involved had changed slightly as already detailed. The 1996 census findings, mentioned above, show that more of the recent immigrants from Korea were reliant on interest, from bank deposits or other investments, than on salary or wages as a source of income in New Zealand (Table 8). Similar findings were obtained in our survey.

\section{Feelings on experiences of living in New Zealand}

In the follow-up interviews, participants were asked to rate, on a ladder with ten rungs, where they were currently standing and to recall where they had been standing when they were first interviewed two and a half years ago (rung 10 represented the best possible life and rung one the worst). An impression of whether the participants were feeling better, worse, or the same with their life and employment in New Zealand can be obtained from their answers to these questions.

\section{Feeling better}

In the group of four participants from Korea, who felt that their life in New Zealand was better at the second interview than it had been at the first, one was living in Auckland and three were living in Hamilton. All four had moved to a different house. The Aucklander, living in New Zealand as a "grass widow" with a son, when first interviewed was living in a suburb on the North Shore and had moved to an inner city apartment. One family was running the entertainment business they were negotiating to purchase at the beginning of 1996 and had moved into a newly built home, another family had sold their inner city ethnic restaurant and taken over the lease of another food outlet serving both Asian and non-Asian food. The wife continued to run the business full-time while the husband assisted on a part-time basis when he had finished his waged employment. The third family had moved to a home where the husband had converted the garage to a salon where his wife, an experienced hairdresser, had begun a business.

\section{Feeling the same}

Three participants rated their satisfaction with life in New Zealand as the same at present as it had been two and a half years ago. Two of the families gave their rating as seven while the second participant in Auckland felt he and his family remained between rungs three and four. The continued low rating of satisfaction for this businessman, who was running a niche market export business, was due to the downturn in business associated with the sudden collapse of the Korean economy. If business had been as good as in 1997 the participant expected he would have felt between six and seven. He expressed a concern that if business continued to be as depressed in the second half of 1998 as it had been in the first half of the year most of the businesses dealing with this product would be forced to close down especially those who did not have specialist knowledge of the business. However, he said that he could withstand this depression because he was engaged in work he was familiar with in Korea before emigrating and "had the special know how" for this business.
The other two families continued to rate their feelings of satisfaction at seven. In spite of the fact that they had experienced difficulty in finding employment and their satisfaction with their financial situation was rated two, a family in Auckland tried to remain optimistic about their everyday life. Their children were doing well at school and in their extra-curricula activities and they had very close "kiwi friends". Although not very satisfied with his horticultural business, a participant in Hamilton felt very comfortable with his life in New Zealand. He was preparing to try and sell his farm though and move back to live in the city.

\section{Feeling worse}

Finally, three participants from Korea felt that their present life was worse than it had been two and a half years ago. Two of the participants gave ratings for present feelings that were three points less than for their feelings of satisfaction when first interviewed. One in his mid 40 s had come to New Zealand under the business investment category and was still living as a retired worker. Although he loved playing golf he was still considering the possibility of doing business in New Zealand but finding it difficult to get started and his rating dropped from eight to five. He was personally more satisfied with his life in New Zealand than his wife. They mentioned that it would be hard for their son to find a good job in New Zealand and that "some-day he may want to return to Korea for a job and we will be happy for him to do so if he can't get work in New Zealand."

The other Korean participant who was feeling much worse than when first interviewed was a woman running an Asian food store while her husband did a polytechnic course to retrain for employment. This woman was finding it difficult to combine the running of her business with her family and household chores and her rating dropped from seven to four. When first interviewed they had just bought and begun to operate the business and the income from the shop had been higher than it was in 1998. She had expected at the end of 1995 that by 1998 she would have had a better life but she has found that "there is nothing easy about life in New Zealand".

Another woman had moved from a rating of seven at the first interview to six. Since mid 1996 this woman had been living in New Zealand as a "grass widow" and being separated from her husband was the reason her feelings about her life in New Zealand were worse than previously. However she was adamant that the rating for her feelings of satisfaction would increase once her husband came back to live in New Zealand.

\section{Conclusion}

The Koreans in New Zealand have been generally disappointed by their employment experiences in this country. This is in contrast to the Korean immigrants to the United States in the 1960's and 1970's. These earlier settlers had little capital and minimal qualifications and were prepared to take up any jobs to establish themselves in their host 
society. The Korean immigrants to New Zealand in the 1990 's were in a very different financial situation and most had very different attitudes to employment. They had left their home country, Korea, when it was at a peak of economic prosperity and had brought capital and skills with them to New Zealand. It was not surprising that at first most were not prepared to take just any job. This is the reason that Korean immigration to New Zealand is unique among the overseas Korean settlers as emigration to New Zealand did not begin until the 1990's.

Although these immigrants were from a middle-class background with considerable education, skills and capital resources it could not be assumed that they would be able to settle without encountering problems. In any society newcomers face a series of tasks that may take a surprising amount of time and energy. In addition to becoming accustomed to their new environment they need to understand the existing institutions and practices to enable them to participate in their new economic and social setting. For immigrants, particularly those who are not fluent in the language of the resident population, the barriers that exist in performing these tasks can be formidable. Knowing the language of business and social discourse not only broadens the labour market opportunities it also increases the receipt of information about the new society (Ip, Wu and Inglis, 1998, 84).

The employment status of Koreans in New Zealand falls into two categories - the employed and the unemployed. For those earning income from employment there are three sub-categories of employment. The largest category is the self-employed and within this group most are engaged in ethnic businesses - a common phenomena among immigrant communities at an early stage. The second category is waged employment. This category contains very few Korean as they are competing with members of the host society for suitable jobs and are at a disadvantage with regards to fluency in the language of the host country and a lack of local qualifications and work experience. The third category is continued employment overseas, usually for the husband who then supports his family in New Zealand with remittances from overseas.

The unemployed group also fall into three subcategories. The first are those receiving some form of government benefit - either a student allowance or loan or unemployment benefit and family support. The second category contains those people who have opted to call themselves retired, as they have been unable to find employment and have not been able to begin a business. The third category contains the unemployed that are actively seeking a job.

In spite of the relative wealth and high educational qualifications of most of the immigrants from Korea, they have still suffered considerable disruption, mental and emotional stress as a result of migrating to New Zealand. Although, most Koreans may have arrived planning to settle permanently, it must be kept in mind that many of these new immigrants, especially those with marketable skills and good financial support have either left, or intend to leave, New
Zealand to look for jobs and livelihood in countries such as Australia, USA, and Canada (Yoon, 1998). Although it is difficult to collect accurate statistics on Koreans who have departed, residents of the Korean community are certain that a considerable number have either re-emigrated to a third country or returned to Korea.

\section{Future research}

Special attention needs to be given to the nature of smallscale ethnic businesses and the cultural and ecological functions of these within the ethnic groups. The establishment of a small-scale ethnic business is one of a few available options for new arrivals in their effort to support themselves and their families. Ongoing observations on employment patterns and changes in patterns of employment would help to provide an understanding of how the employment patterns of immigrants evolve over time. For example, a recent de velopment in Korean self-employment in Auckland is the movement of considerable capital into market gardening enterprises on the fringes of South Auckland. This is an unexpected development as there were no Korean immigrants with previous market garden work experience. A sense of the changes that occur within the general employment status of immigrants over time as they adapt to life in the host society is needed. This would assist in the formulation of helpful post-settlement policies.

\section{References}

Bradford, M. (1997a) Closing address, The Population Conference Proceedings Disk, Corporate Arrangements Ltd, Wellington, 302-307.

Chan, K.B. and Chiang, S.N.C. (1994) Stepping Out: The Making of Chinese Entrepreneurs, Prentice Hall, Singapore.

Delamere, T. (1998) Making New Zealand a More Attractive Destination, Press Release, Minister of Immigration, 12 October, $2 \mathrm{pp}$.

Foster, W., Gruen, F. and Swan, N. (1994) Economic effects on the host community, in Adelman, H., Borowski, A., Burstein, M. and Foster, L. (eds), Immigration and Refugee Policy: Australia and Canada Compared Vol II, Melbourne University Press, Australia, 445-471.

Ho, E., Goodwin, J., Bedford, R. and Spragg, B. (1997) Migrants in the workforce: A preliminary comparison of Chinese and Korean recent immigrants in 1991 and 1996, Briefing Paper prepared for participants in the Population Conference, 12-14 November, Wellington.

Ho, E.S., Bedford, R.D., Wong, S.L. and Tang, M. (1998) Entrepreneurial activities of Hong Kong migrants in New Zealand and Hong Kong, in Migrant Entrepreneurship and the Development of New Zealand's Links with Hong Kong. Proceedings of a Workshop Organised by the Migration Research Group, 25 July 1009. University of Waikato, Hamilton (forthcoming) 
Ip, D., Wu, C-T. and Inglis, C. (1998) Settlement experiences of Taiwanese immigrants in Australia, Asian Studies Review, 22(1), 79-97.

Li, P.S. (1993) Chinese investment and business in Canada: ethnic entrepreneurship reconsidered, Pacific Affairs, 66(2), 219-243.

Lidgard, J.M. (1996) East Asian Migration to Aotearoa/ New Zealand: Perspectives of Some New Arrivals, Population Studies Centre Discussion Paper No 12, University of Waikato, Hamilton.

Lidgard, J.M. (1998) Northeast Asian Migration: Recent Change in New Zealand's International Migration System. Unpublished PhD thesis, University of Waikato, Hamilton.

Lidgard, J., Ho, E., Chen, Y-Y., Goodwin, J. and Bedford, R. (1998) Immigrants from Korea, Taiwan and Hong Kong in New Zealand in the mid1990's: Macro and micro perspectives, Population Studies Centre Discussion Paper No 29, University of Waikato, Hamilton.

New Zealand Yearbook, (1998) Statistics New Zealand, Government Printer, Wellington.

Seok, H. (1998) International labour migration and financial crisis in Korea, Paper presented at the Migration Workshop, At the Crossroads: Migration and the Financial Crisis in Asia? 17-18 October, Australian National University, Canberra.

Skeldon, R. (1998) Migration of entrepreneurs from Hong Kong: background, trends and impacts, in Migrant Entrepreneurship and the Development of New Zealand's Links with Hong Kong. Proceedings of a Workshop Organised by the Migration Research Group, 25 July 1009. University of Waikato, Hamilton (forthcoming).

Statistics New Zealand (1996) Individual form, Census 5 March, Statistics New Zealand.

Stone, A. (1998) Migrant misery: our Govt owns up, New Zealand Herald, 5-6 September, A1.

Yoon, H-K. (1998) Searching for a Korean identity, Paper presented at a Workshop on Building Blocks of National Identity: Population in New Zealand History 16-17 April, Population Studies Centre and Department of History, University of Waikato, Hamilton.

Winkelmann, L. (1997) Population change and the labour market, in Proceedings of the Population Conference, 12-14 November 1997, NZIS, Wellington, 128-136.

\section{Acknowledgements}

The authors wish to acknowledge assistance received from the Foundation for Research, Science and Technology for financial support, and members of the Korean Communities in both Auckland and Hamilton who participated in the interviews.

\section{Authors}

Jacqueline Lidgard is a Research Fellow in the Geography Department, University of Waikato, Private Bag 3105, Hamilton.

E-mail: jml@waikato.ac.nz

Hong-key Yoon is an Associate Professor in the Department of Geography, University of Auckland, Private Bag 92019, Auckland.

E-mail: hk.yoon@auckland.ac.nz 